\title{
EXPERT JUDGEMENT OF MUTUAL INFLUENCE AMONG LAND DEGRADATION DETERMINATION CRITERIA
}

\author{
Dace Platonova, Velta Parsova, Anda Jankava, Maija Berzina \\ Latvia University of Agriculture \\ dace.platonova@gmail.com; velta@parsova.lv; anda.jankava@llu.lv; maija.berzinaaa@gmail.com
}

\begin{abstract}
Land is a non-renewable resource with limited availability and, therefore, a very important issue is the preservation of useful properties of land and comprehensive and sustainable land use. The process of land and soil degradation (decline of properties) leading to the formation of degraded land have been observed due to the influence of various economic activities and environmental conditions. The Land Management Law has already specified that degraded land is an area of destroyed or damaged land surface or abandoned territory of building sites, mineral extraction, economic or military activity. The expert opinion on degraded land is that it could be a polluted area, abandoned building sites, old greenhouse territories, Soviet-period farms and workshops, as well as non-recultivated mineral deposit sites and dumping grounds. The research concluded that currently it is useful to distinguish three types of degraded land: abandoned building sites, an abandoned mineral extraction area and an abandoned agricultural and forestry activity area. The Analytic Hierarchy Process developed by American mathematician T.L.Saaty was applied for choosing criteria for each type of degraded land to identify the views of experts on the mutual influence of land degradation determination criteria. The results of the expert evaluations showed that the most important criteria for the determination of abandoned building sites and agricultural and forestry activities were "dump-site" and "abandoned military territory or object".
\end{abstract}

Keywords: land degradation, criteria, degraded territories, Analytic Hierarchy Process.

\section{Introduction}

Land and soil degradation (decline of properties) processes take place due to various economic activities and natural conditions, resulting in degraded territories. A degraded territory is a land area that has been damaged by industrial or another kind of activity or inactivity to the extent it is not possible to exploit this area economically efficiently without taking special rehabilitation measures.

The urgency of the problem of soil degradation at international level and at national level in Latvia began being realised a number of years ago. In their research investigations, both foreign and national scientists have placed a quite significant focus on land and soil degradation, yet their research papers mainly focused on soil degradation, its effects and measures to be taken to avoid it [1-4].

The degradation of territories is a relatively new problem in the Baltic States; therefore, the terminology has not been fully developed, recognised and used in government policy documents and legal acts. To date, land degradation problems have been tackled from different perspectives, and territories where diverse, environment-unfriendly processes and their effects were in place were attributed to degraded territories, e.g. waste-polluted territories, territories occupied by invasive plant species, abandoned former military objects etc. [5;6]. However, in other European countries degradation problems have been addressed in their political agendas since the middle of the last century. For this reason, it is important for the Baltic States, including Latvia, to define the right characteristics of degraded territories and integrate them in the national legislation and the political framework.

As regards land degradation risks and the prevention of the risks in Latvia, the Land Management Law came into force on 1 January 2015, defining the terms land and soil degradation and making local governments responsible for depicting degraded territories in policy documents and land owners responsible for taking measures to avoid land degradation. Furthermore, from 2018 onwards the government is obliged to produce a report on land every five years, which has to include information on degraded territories and their area. However, despite what the law prescribes, criteria for the identification of land and soil degradation have not been developed and approved in Latvia until now; that is why the criteria available are very subjective and incomparable across municipalities and at national level. This makes it necessary to perform a comprehensive assessment of the mentioned criteria and their mutual influence.

The aim of research is to identify the kinds of degraded territories (land) and to develop criteria for their identification in order to establish expert opinions on the mutual influence of land degradation determination criteria. 
The object of the research is the land degradation process, while the subject of the research is criteria for land degradation determination.

\section{Materials and methods}

To establish expert opinions on the mutual influence of land degradation determination criteria, the research employed American mathematician T.L.Saaty's Analytic Hierarchy Process. By means of this method, elements of any problem are systemised, the problem is divided into simple details and experts compare pairs of the details, assessing interaction among the problem's elements [7]. An important prerequisite for creating a hierarchy is to correctly divide its elements by level. For this purpose, a hierarchy is created, in which the overall goal is at the top, while criteria groups are placed at the next level.

A hierarchy was created based on the results of a survey of municipal and national institution specialists, which allowed concluding that at present in Latvia it is useful to distinguish three kinds of degraded territories (land): degraded built-up territory, non-recultivated territory of mining of mineral deposits and unmanaged agricultural and forestry activity territory.

At present, it is important to acquire data only on degraded built-up territories and unmanaged agricultural and forestry activity territories; therefore, two hierarchies were created.

Hierarchy I "Degraded built-up territory" (level 1); the following criteria were selected for the hierarchy (level 2):

- depreciation of buildings;

- built-up territory overgrown with bushes;

- pollution;

- dump-site;

- abandoned production territory or facility;

- abandoned military territory or object.

Hierarchy II "Unmanaged agricultural and forestry activity territory" (level 1), the following criteria were selected for the hierarchy (level 2):

- agricultural land overgrown with bushes;

- dump-site;

- abandoned production territory or object;

- abandoned military territory or object;

- invasive plants;

- swampy land;

- pollution.

The criteria for degraded territories (land) were selected according to each kind of the territories in order to identify the degree of significance of the criteria. To evaluate the criteria, five experts were involved based on a condition that the number of the experts had to be limited. The number of experts does not have to be large because otherwise the average competence of the experts' group might decrease. However, it has to also be taken into consideration that the subjective opinion of an expert in a small expert group can significantly influence the concordance of their ratings [8].

The experts were selected from various target groups, taking into account their contribution to their field of activity. Among the experts, there were practicians - representatives of area of agriculture, forestry, environmental protection, land management, water management, real estate cadastre, as well as leading researchers from Latvia University of Agriculture and Riga Technical University were also involved to evaluate the criteria; the researchers extensively discussed the criteria for identifying the kinds of degraded territories (land). Each expert was denoted by a Latin capital letter from A to $\mathrm{E}$.

\section{Results and discussion}

The experts' evaluation of Hierarchy I "Degraded built-up territory" criteria demonstrated great diversity in their opinions. However, most of the experts gave the highest ratings to the criteria "dump- 
site" (priority vector 0.31 ) and "abandoned military territory or object" (priority vector 0.27 ). The experts ranked the criterion "pollution" (priority vector 0.20 ) in the third place, the criterion "abandoned production territory or object" (priority vector 0.14 ) in the fourth place, the criterion "depreciation of buildings" (priority vector 0.06 ) in the fifth place and the criterion "built-up territory overgrown with bushes" (priority vector 0.03 ) was the last one rated by the experts who ranked it sixth (Figure 1).

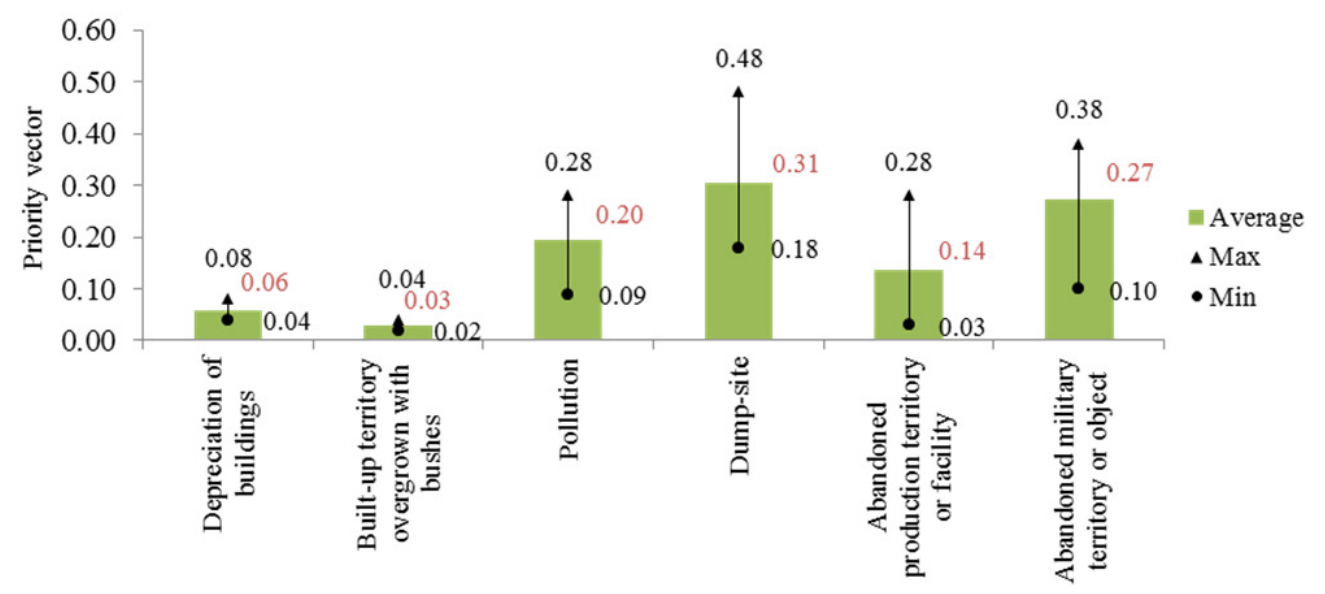

Fig. 1. Expert ratings of criteria for degraded agricultural and forestry territories

Besides the arithmetic average value of the priority vector, also the minimum (min) value and the maximum $(\max )$ value were calculated for each criterion analysed (Figure 1). The greatest variation around the average value was observed for the criteria "dump-site", "abandoned military territory or object" and "abandoned production territory or facility", which indicated the diversity in the experts' opinions on the mentioned criteria, as the experts represented different target groups whose priorities in evaluating the criteria were different.

A relatively little variation around the average value was observed for two criteria, i.e. "built-up territory overgrown with bushes" and "depreciation of buildings", which indicated the significance of the criteria in the opinion of all the experts evaluating Hierarchy I.

The experts' evaluation of Hierarchy II 'Unmanaged agricultural and forestry activity territory" criteria also reflected large diversity in the experts' opinions. However, most of the experts, just like in the evaluation of Hierarchy I "Degraded built-up territory", gave the highest ratings to the criteria "dump-site" (priority vector 0.30) and "abandoned military territory or object" (priority vector 0.24 ). The experts placed "pollution" (priority vector 0.18 ) in the third place, the criterion "abandoned production territory or object" (priority vector 0.12 ) in the fourth place, the criterion "invasive plants" (priority vector 0.07 ) in the fifth place, the criterion "swampy land" (priority vector 0.04 ) in the sixth place and the criterion "agricultural land overgrown with bushes" (priority vector 0.04 ) was the last one rated by the experts who ranked it seventh (Figure 2).

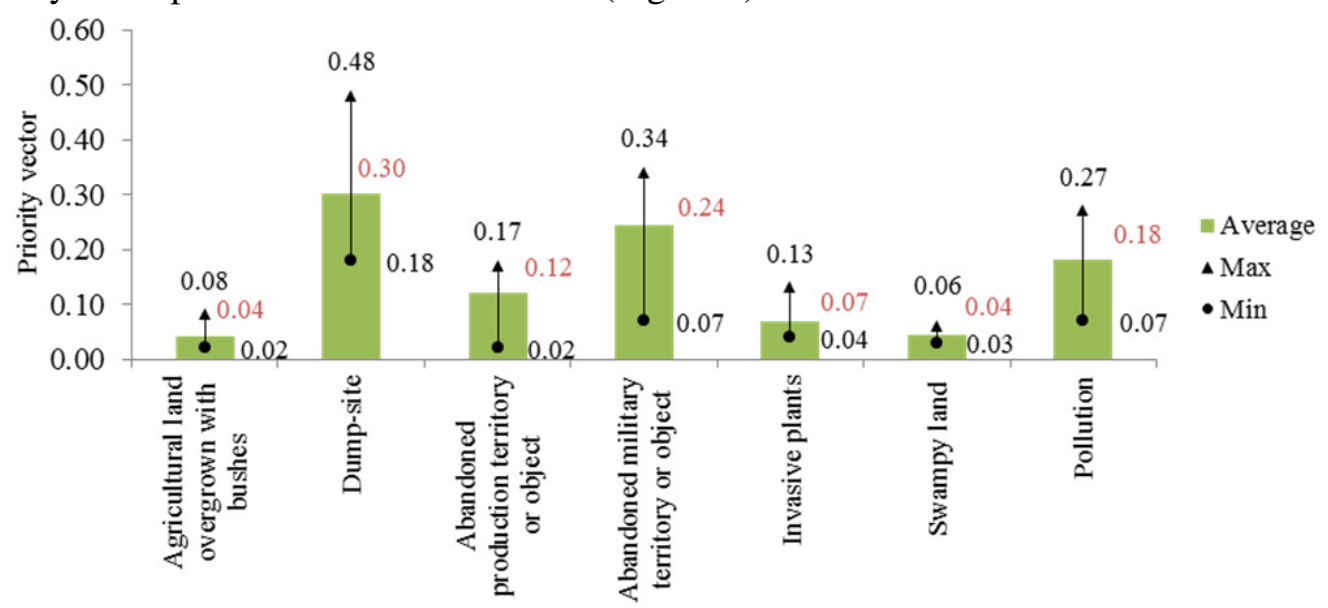

Fig. 2. Expert ratings of criteria for degraded agricultural and forestry activity territories 
Just like in the evaluation of Hierarchy I, besides the arithmetic average value of the priority vector, also the minimum (min) value and the maximum $(\max )$ value were calculated for each criterion analysed (Figure 2). The greatest variation around the average value was identified for the criteria "dump-site", "abandoned production territory or object" and "pollution", which once again confirmed that the experts represented various target groups and their priorities in rating the criteria were different.

However, a relatively little variation around the average value was demonstrated by the criterion "swampy land", which pointed to the significance of this criterion in the opinion of all the experts evaluating Hierarchy II.

\section{Conclusions}

1. The Land Management Law in Latvia pays attention to the risks of land degradation and their prevention, however, an appropriate classification of degradation has not been developed yet; there is no regulation of the procedure how to recognize and evaluate the current degree of land degradation or its possibility. Land degradation processes do not occur only in agricultural land, they can take place in both rural and urban territories.

2. In identifying degraded territories, it is advised to classify the territories as follows: degraded built-up territory, non-recultivated territory of mining of mineral deposits and unmanaged agricultural and forestry activity territory, which may be identified according to the characteristics typical of them.

3. The evaluation made by the experts allows concluding that the criterion "dump-site" is the most important both for degraded built-up territories and degraded agricultural and forestry territories. For degraded built-up territories, a significant criterion is "abandoned industrial territory or facility", while for degraded agricultural and forestry territories - "abandoned military territory or object"

4. The results of the survey and interviews of national and local government specialists prove that manifestations of types of land degradation are very different, therefore, a systematic approach to the recognition and evaluation of the situation is necessary.

\section{References}

1. Jankauskas B., Jankauskiene G. Erosion-preventive crop rotations for landscape ecological stability in upland regions of Lithuania. Agriculture, Ecosystems \& Environment. [online] [08.02.2017.]. Available at:http://www.sciencedirect.com/science/article/pii/S0167880902001007

2. Juozapavičiūte K. (2016). Mokslininkai: pastaraisiais metais stebima ryški Lietuvos dirvožemio degradacija. Žalioji Lietuva (Scientists: Recent Years have Seen a Sharp Degradation of Soil in Lithuania. The Green Lithuania) (in Lithuanian). [online], [08.02.2017.]. Available at: http://www.delfi.lt/grynas/aplinka/mokslininkai-pastaraisiais-metais-stebima-ryski-lietuvosdirvozemio-degradacija.d?id $=59214483$

3. Kḷaviņš M., Nikodemus O., Segliņš V. et al. Vides zinātne (Environmental science), Publishing house "The Academic Press of the University of Latvia", Riga, 2008. 599 p.

4. Land Degradation. United Nations Environment Programme. [online] [08.02.2017.]. Available at: www.unep.org/dgef/LandDegradation/tabid/1702/Default.aspx

5. Jackson J.B., Finka M., Hermann G., Kliučininkas L., Lemešenoka N., Petriková D., Pletnická J., Teirumnieks E., Velykienė D., Vojvodíková B., Zahnašová M., Zubková M. Degradētās teritorijas. Rokasgrāmata. Starpdisciplinārs mācību līdzeklis degradēto teritoriju atjaunošanai. Mācību līdzeklis Latvijai un Lietuvai (Degraded Territories. Handbook. Interdisciplinary study aid for restoring degraded territories. Study aid for Latvia and Lithuania) (in Latvian). Faculty of Civil Engineering, VŠB - Technical University of Ostrava, Ostrava, 2010. 140 p.

6. Brabant P. A land degradation assessment and mapping method. A standard guideline proposal, No 8. CSFD/Agropolis International, Montpellier, France, 2010. 52 p.

7. Saaty T.L. Decision making with the analytic hierarchy process. International Journal of Services Science, Volume 1, No 1, 2008. pp. 83-97.

8. Vasermanis E., Šķiltere D., Krasts J. Prognozēšanas metodes (Methods of Forecasting) (in Latvian). Riga: LU, Izglītības soḷi, 2004. 121 p. 